Z Badań nad Książką i Księgozbiorami Historycznymi 2019, t. 13

The Studies into the History of the Book and Book Collections 2019, vol. 13

ISSN 1897-0788, e-ISSN 2544-8730

www.bookhistory.uw.edu.pl

DOI: 10.33077 uw.25448730.zbkh.2019.170

Ewa Repucho

Department of Information and Library Science

University of Wrocław

ewa.repucho@uwr.edu.pl

ORCID 0000-0001-7532-8244

\title{
The book collection of Jan Kuglin as a source for research on the aesthetics of print in the $20^{\text {th }}$ century
}

\begin{abstract}
The paper describes a somewhat forgotten book collection of the outstanding Wrocław editor Jan Kuglin, in terms of the editions on print aesthetics contained therein. The collection, which is a reflection of Kuglin's scientific passions, contains many valuable books in German, English, Polish, Russian and Czech in the field of book and printing history, editing, book design, typography, writing, graphic techniques, polygraphy, paper industry, bookbinding, etc. In the book collection of Kuglin one can find editions being examples of a perfect typography. Thus, the collection stored in the Library of the Institute of Information and Library Science of the University of Wrocław is an excellent source for research on the aesthetics of printing in the $20^{\text {th }}$ century.
\end{abstract}

Key words: Jan Kuglin - library - book collection - publishing - print aesthetics - typography poligraphy - printing.

„Z Badań nad Książką i Księgozbiorami Historycznymi” - Udział zagranicznych recenzentów w ocenie publikacji; Stworzenie anglojęzycznej wersji wydawniczej publikacji; Digitalizacja tomów archiwalnych rocznika w celu zapewnienia otwartego dostępu do nich przez Internet oraz wdrożenie i utrzymanie cyfrowej platformy redakcyjnej - zadanie finansowane w ramach umowy nr 653/P-DUN/2019 ze środków Ministra Nauki i Szkolnictwa Wyższego przeznaczonych na działalność upowszechniającą naukę. 


\section{A beautiful book in Jan Kuglin's life}

A lot has been written about Jan Kuglin, an outstanding bibliophile and typographer, as well as an expert, in printing ${ }^{1}$. His biography and merits in editing, and promotion of aesthetics of printing in particular, are commonly known. It is also well known that Kuglin, a book expert and lover, possessed a rich book collection. Information that his collection of art prints was passed to the National Museum in Wrocław can be found in the Internet version of the Encyklopedia $P W N^{2}$. However, there is no mention that another - much larger - part of his collection, of a book science profile, was donated to the Department of Librarianship and nowadays it belongs to the Library of the Institute of Information and Library Science, the University of Wrocław. This collection has been forgotten by many, and younger generations are not aware of its existence. The more it is worth to be presented and characterised in regard to aesthetics of printing, which was of particular importance for Kuglin.

Jan Kuglin's book collection reflects his professional life, interests and passions as a mirror. It is worth to trace biography of the well-known bibliophile to perceive that. He was born in Bogumin in 1892, and his taste for the books came from his home. His father, a steelworker and a blacksmith, had been working as a librarian and chairman of the Folk Reading Society and the Macierz Szkolna educational organisation in Bogumin for many years. At the same time, he gathered his own book collection, amounting to hundreds of volumes, including many valuable ones: early printed books, old hymnals, Polish literature of that time and volumes of Polish journals from all partitions $^{3}$. Kuglin remembered that raised among books, he knew as a child about Załuski and his book collection. His first childish dream was "to establish a library as significant as that of Załuski in Poland"4. Kuglin graduated from the

1 See for example: U. Gumuła, Jan z Bogumina Kuglin - twórca pięknej książki, [in:] Ksiązka polska na Ślasku w latach 1922-1945. Zarys problematyki, ed. by M. Pawłowiczowa, Katowice 1994, pp. 224-234; J. Kucharek, Jan Kuglin - drukarz-bibliofil, MA thesis, tutor: S.J. Gruczyński, Wrocław 1976; G. Talar, Jan z Bogumina Kuglin-drukarz i bibliofil (1892-1972), "Roczniki Biblioteczne" 1973, no. 1-2, pp. 417-436; T. Rychlik, Drukarz-artysta z Bogumina, "Zwrot" 1972, no. 11, pp. 25-26; J. Radko, Jan Kuglin, "Poglądy" 1971, no. 10, pp. 4; A. Skiba, Doktor Jan z Bogumina Kuglin, "Wiadomości Graficzne" 1969, no. 3, p. 6; G. Talar, Jan z Bogumina Kuglin, [in:] Słownik Pracowników Ksiązki Polskiej. Suplement, Warszawa 1968, p. 113; J. Kuglin, Ze wspomnień typografa, Wrocław 1958; Z. Bednorz, Trud i dzieło pewnego «Ślężoka», "Odra” 1948, no. 48, pp. 3-4; A. Jesionowski, Biblioteka Jana Kuglina, "Wici Wielkopolskie. Miesięcznik poświęcony sztuce i kulturze" 1935, vol. 5, no. 2 (41), p. 10; A. Jesionowski, Jan Kuglin-twórca pięknej książki, "Polska Zachodnia" 1934, no. 172, p. 3.

2 Jan Kuglin, [in:] Encyklopedia PWN [online], https://encyklomehpedia.pwn.pl/haslo/Kuglin-Jan;3928682.html [retrieved on: 14.07.2018].

3 U. Gumuła, Jan z Bogumina Kuglin..., p. 225.

4 J. Kuglin, Ze wspomnień typografa..., p. 9. 
German folk school and as a 14 years old boy started work in a small printing house of Jan Smuda in Bogumin, printing mostly the ephemera. Then he continued education in a classic secondary school in Cieszyn, where he was also engaged in printing works - i.e. typesetting and proofreading in the Mitręga printing house. However, he was removed from the school for his activity in the Education and Independence Circle, and for distribution of socialist magazines and books for the youth ${ }^{5}$. He moved to Cracow, where he graduated the St. Jack secondary school. In Cracow he met Józef Mehoffer, professor and rector of the Academy of Fine Arts in Cracow, who influenced significantly his further works and interests in aesthetic of prints. Mehoffer drew his attention to the beauty of external aspects of books: shape of covers, title pages, as well as decorative material: ornaments, mastheads, initials, delimitations, etc. ${ }^{6}$ At Mehoffer's instigation young Kuglin wanted to enter the Graphische Versuchsanstalt in Wien. Unfortunately, these plans failed. He was recruited to the army and went into captivity as an Austrian prisoner at the Russian front. After a year he was brought to Moscow. He did start working in the printing house of Wilhelm Lehman there, and later in the Polish Printing House of Michat Głodkowski. He also engaged in publishing works of the Literary and Artistic Circle, which aimed at publishing sophisticated editions. Janusz Bogucki and Karol Homolacs were responsible for artistic section.

I encountered [that time], practically for the first time - Kuglin recalled - with the issue of beauty in a book. [...] [Tadeusz] Miciński and [Marian] Morelowski were particular advocates of the beauty of prints in these works. Under their influence, and in particular advised by Morelowski, I started studying the literature concerning beautiful book and history of the book, and history of the Polish book in particular, available in Moscow?

During his practice in Moscow Kuglin collected adequate literature, which he later managed to transfer to Poland. He described this collection in the article published in the "Przegląd Graficzny" (Graphics Review) in 1926. This journal was established on Kuglin's initiative in 1919, after his return to Poland. it was to join a printing community, informing about organisational and technical matters ${ }^{9}$. That time Kuglin worked as a typesetter in the Polish Printing House. Another initiative important for the profession was the establishment of the Graphic Society at the Union of the Polish Printers, which "aimed at the development of professional and general knowledge of the printers, and in

5 U. Gumuła, Jan z Bogumina Kuglin..., p. 227.

6 A quite worn out copy of the book concerning Mehoffer's works can be found in Kuglin's collection a: H. de Franqueville d'Abancourt, Grafika książowa Józefa Mehoffera na tle prądów wspótczesnych, Kraków 1929.

J. Kuglin, Ze wspomnień typografa ..., p. 12.

8 J. Kuglin, Literatura księgoznawcza w Rosji, "Przegląd Graficzny" 1926, no. 37.

9 J. Kuglin, Ze wspomnień typografa ..., p. 12. 
particular promotion of the beauty of print" ${ }^{\prime 10}$. Kuglin had been a chairman of the Society for many years. He perceived this function as a particular obligation to supervise the beauty of prints. A bibliophile movement had been intensively developing in that time, therefore Kuglin not only observed their activities but also engaged in activities for the benefit of the beautiful book, and initiated publishing activities. Two his famous bibliophile series deserve special attention: "Biblioteka Stu Dwudziestu" (The One Hundred and Twenty Library) and "Biblioteka Jana z Bogumina Kuglina" (The Jan of Bogumin Kuglin Library). Years later he recalled: "Influenced by this great, almost worldwide movement for the revival of beauty in a book, I decided to act also in this range [...]. I started my individual experiments in a small printing house of my own" 11 . This was the "Poradnik Gospodarski" printing house. In 1926 Kuglin organised there the first in Poznań course of artistic binding and initiated the movement of renewal of the art of binding. He also engaged in publishing of the "Polska Gazeta Introligatorska"12 (Polish Binding Daily).

Urszula Gumuła underlines that a high quality of Kuglin's publications resulted also from the contact with the Poznan School of Ornamentation, in particular, cooperation with Wiliam Ossecki and Stanisław Lam ${ }^{13}$. Kuglin, like Lam, was delighted at beauty of clear typographic layout in a book. Out of his hands books were coming, "about which it was written that there was a beauty of prints of Gutenberg or Aldus Manutius in them. Out of his hands books of Plantin were coming, and that these are not simply books for reading, but rather works of art [...]. Kuglin was also presented as a worthy heir of a noble printing art inherited from the Haller, Lazarius, Wirzbięta, Gröll, Korn, and other famous typographers"14. His attitude towards work was very emotional, as proved for example by this published fragment of memoirs:

many times, tired of all day work - I stopped in a dimness of evening or night silence among quiet devices, shelves, cases and sleeping printer's devils - and caressing type after type, I ordered them in a material form...- a thought. I tried to find the noblest types even among French, Dutch or Italian ones - to give the most beautiful typographic form to a thought $[\ldots]^{15}$.

In the piece of a story Jak powstaje ksiażka (How the book is made) published in 1933, written by Kuglin for the children to approach them the secrets of printing workshop, an important thought arises. The book from this story is

10 Ibidem, p. 12.

11 Ibidem, p. 14.

12 E. Pokorzyńska, Polska Gazeta Introligatorska. Dzieje czasopisma i analiza zawartości, [in:] the Kazimierz Wielki University Repository, 2013, p. 46 [online], http://repozytorium.ukw.edu. $\mathrm{pl} /$ handle/item/3842 [retrieved on 29.08.2018] .

13 U. Gumuła, op. cit., p. 229.

14 Ibidem, p. 233.

15 A. Jesionowski, Biblioteka Jana Kuglina ..., p. 10 (Kuglin's foreword to "Powsinogi” by Zegadłowicz). 
absolutely conscious of the necessity of cooperation among an author, a printer and an artist, to reach the most beautiful external form. The book was illustrated by the outstanding artist Władysław Roguski, Mehoffer's student and lecturer in the School of Fine Arts in Poznań:

Well, my author wanted me to look very beautiful [...] - said the book. - The printing house chief agreed in this matter with mister Roguski, a painter, and he drew a number of colourful pictures for me, many decorative initials, a few sketches presenting different scenes from my stories, and a number of smaller decorations, which are tailpieces at the end of each section and chapter ${ }^{16}$.

In the following part of the story, another outstanding painter is introduced, professor of the Academy of Fine Arts in Cracow, Leon Wyczółkowski ${ }^{17}$.

After World War II Kuglin actively joined reconstruction of printing in Silesia. He was engaged in organisational works, among others he contributed to opening a few dozen of printing houses in Upper Silesia. In 1949, he became a director of the University and Polytechnic Printing House in Wrocław, renamed in 1953 into the Wrocław Scientific Printing. He was interested in particular in scientific printing that time, including exact sciences, natural sciences and the humanities, and, more specifically, the method of typesetting of scientific texts. For example, he published the instruction of typesetting mathematical prints in cooperation with Bronisław Knaster, member of the Wrocław Scientific Society. Kuglin's huge experience was useful also in his teaching work, for example in the years 1958-1972 he worked as a lecturer in the University of Wrocław. He taught printing and graphic techniques in the Library Science Part Time Studies, and later in a regular course as well, and the students of the Higher School of Fine Arts and in the Wrocław Technical College of Polygraphy. At the same time he shared his knowledge, writing textbooks for students and pupils. He was also an author of publications concerning history and aesthetic of printing, and the commonly known book "Poligrafia książki" (Polygraphy of the book, two editions in 1964 and 1968), the only one in that time compendium concerning publishing and polygraphic issues.

\section{The book collection donated to the Department of Library Science}

During his stay in Moscow, as well as the rest of his professional life, Kuglin had been collecting professional books, developing a workshop for his scientific works. The collection attracted the attention of Bożena Szulc-Golska,

16 J. Kuglin, Jak powstaje książka. Z cyklu «Przedmioty mówią, Seria Biblioteka Szkoły Powszechnej, Lwów 1933, p. 30. [online], http://dlibra.umcs.lublin.pl/dlibra/plain-content?id=2660. [retrieved on 18.07.2018].

17 Ibidem, p. 31. 
who wrote in 1929 in her publication concerning private libraries from the Greater Poland region ${ }^{18}$ that the Kuglin's library established approximately in 1915 amounted to approximately 1500 volumes "mostly on library science, in the broadest interpretation of this term" 19 . Her text indicated that the library included Polish, Czech, Russian, German, French and English books, valuable works concerning the history of the book and printing in the Slavic countries, and bookbinding. Kuglin gathered also many works concerning the aesthetics of printing, mostly the history of graphic art and book decorations. Bożena Szulc-Golska assumed Kuglin's book collection "as one of the richest libraries concerning book studies in Poland" 20 . The library was exceptional due to beautiful book bindings.

The library, marked with the owner's exlibris, is all binded - Szulc-Golska wrote. - Besides a number of older bindings from the $16^{\text {th }}$ and $17^{\text {th }}$ centuries, there is plenty of elegant and artistic bindings made partially of the owner's designs or decorated personally by him. A few titles of modern literature are decorated with illuminations made by the owner ${ }^{21}$.

Unfortunately, during the World War II, the library was dispersed ${ }^{22}$. Kuglin started again his collection, in Wrocław this time, where he eventually settled. In 1966, 6 years before his death, he declared that collections concerning book studies would be donated to the Department of Library Science of the University of Wrockaw (at present the Institute of Information and Library Science, UWr), and beautiful art and bibliophile prints would be donated to the National Museum in Wrocław.

In 1973, the collection concerning book studies was moved to the Institute, which was seated at the Piasek Island, and then transferred to the new location at the University Square 9/13. However, it was not catalogued in a day nor included to the library, therefore its part has been dispersed. At present Kuglin's books are stored in the new library of the Institute, on separate shelves. The handwritten inventory lists 960 positions. For the time being the Kuglin's collection can be accessed via traditional, card catalogue, but it is to be changed soon - it will be digitised and made available in the VIRTUA system.

Kuglin's books excel with beautiful exlibrises, applied even by himself. He created three types of a proprietary mark: "From among Jan Kuglin's books donated to the Department of Library Science, UW", "Jan Kuglin's exlibris" and

18 B. Szulc-Golska, Wielkopolskie biblioteki prywatne, Poznań 1929, pp. 7-8 [online], http:// www.wbc.poznan.pl/dlibra/doccontent?id=17157 [retrieved on 7.07.2018].

19 Ibidem.

20 Ibidem.

21 Ibidem.

22 M. Gębczak, Biblioteki Jana z Bogumina Kuglina, "Śląskie Miscellanea ” 2004, no. 17, p. 83 [online], http://www.sbc.org.pl/Content/88330/ii499767-0-17.pdf [retrieved on: 29.08.2018]. 
"Exibris Wratislaviensibus Jan of Bogumin Kuglin". Monochrome exlibrises have original, woodcut form, using decorative elements of old book (among others - a motive of a printer at printing machine, old panorama of Wrocław, and decorative architectural or floral motives).

\section{Publications concerning the aesthetics of printing}

Kuglin's book collection, of book studies character, consists of approximately 250 editions concerning the aesthetics of printings; it is a perfect material for research. These are either theoretical or practical works concerning history and modern times. Literature in the German language prevails, however there are also texts in Polish, Czech, English and Russian, published in both first and second half of the $20^{\text {th }}$ century.

Literature from before the World War II is dominated by editions concerning the art of printing, history of the craft, achievements of previous printers, etc. Texts in German prevail, often typed with a fraktur. The oldest positions are the printing textbook by Carl August Franke Handbuch der Buchdruckerkunst, published in Weimar in 1867, and Die Erfindung der Buchdruckerkunst of Heinrich Meisner and Johannes Luther, published in Leipzig in $1900^{23}$.

Undoubtedly, editions concerning the development of book graphic design are of particular value, e.g. the first German edition of the work of known English typographer Stanley Morison Handbuch der Druckerkunst ${ }^{24}$, published in Berlin in 1925. Morison, designer of the famous Times typeface, connected with the Monotype Corporation, on 250 pages placed examples of beautiful, historic typographic settings from the years 1500-1900, which are a perfect lesson of model typography. Another important work of the same author can also be found in the Kuglin's collection, Grundregeln der typographie, published in Berlin in 1955, concerning fundamental rules of typographic setting of a book.

Important is also the German edition of the famous book by Thomas James Cobden-Sanderson Das Idealbuch oder das schöne Buch. Eine Abhandlung über Kalligraphie, Druck und Illustration und über das schöne Buch als ein Ganzes. The book was published in Berlin in 1921. The work of the English artist related to the Arts and Crafts movement concerns the idea of book design as an indivisible whole of all its elements, such as typing, illustrations, decorations, print and binding. Mechanisierte grafik. Schrift. Typo. Foto. Film by Paul

23 Worth noting are the books: Lehrbuch der Buchdruckerkunst by August Müller, published in Leipzig in 1913; Das alte Buch by Karl Schottenloher, a librarian of the Municipal Library in München, published in Berlin in 1919; Die Kunst Gutenbergs by Hermann Barge, professor of the University of Leipzig; Geschichte der Buchdruckerkunst, published in Leipzing in 1940 and Julius Rodenberg's Die Druckkunst als Spiegel der Kultur in fünf Jahrhunderten, published in Berlin in 1942.

24 Original title: The art of the printer. 
Renner, an outstanding typographer known as a designer of the Futura typeface, also belongs to classical works concerning graphic and edition design. This book was published in 1930 in Berlin as a specific manifesto of modern design of that time. It concerns different aspects of edition design, which have been modernising due to mechanisation. Interesting is also the typographic setting of this edition in the spirit of new typography - it was typed with onepiece sans serif Antiqua. The form perfectly complements the content. Among particularly valuable editions concerning the external design of a book, there is the one Methods of Book Design. The Practice of an Industrial Craft by the British designer Hugh Williamson, connected with the Oxford University Press. It was published in London in 1956 and had many reissues, as it presents timeless, still relevant truths. Kuglin received it as a present from the Łódź Scientific Society, as proved by handwritten dedication on December $21^{\text {st }}, 1957$. A copy of Kuglin's letter to the LSS chairman, found inside the book, reveals that it became "an invaluable handbook and a steaming pile of news" 25 for him. Important research sources among English language works are two exhibition catalogues: The Second International Exhibition of Book Design from 1947 and the British Book Design from 1957. They were published on the initiative of the National Book League in London, and consist of the selection of the most beautiful books published in Great Britain in the years 1946 and 1956. There are also two catalogues Spiegel Deutscher Buchkunst in Kuglin's collection, listing the most beautiful German books awarded in the contests Die Schönsten Bücher des Jahres 1953/54 and 1955. These positions are very good sources of information concerning post-war trends in book design in Western Europe.

There are also important editions concerning more specific issues of the aesthetic of print. First of all, Kuglin collected vast literature on script as a fundamental mean of expression in typography. He possessed works concerning its history and development of graphic form within centuries, typefaces and their legibility. Among the oldest, pre-war editions there are Die Entstehung der Frakturschrift by Rudolf Kautzscht (Mainz, 1922) and Ausgewählte Druckschriften by Emil Wetzig (Leipzig, 1925). Important is also the book of Christian Heinrich Klenkens Die Kunst der Letter, published in Leipzig in 1940, the one of Helmut Eckelmann Zur Entwicklung der Buchdruckschrift, edition from 1950, Frankfurt-am-Main. Present, too, are both editions (1957 and 1960) of the commonly known book of Czech authors Oldřich Hlavsa and František Sedláček Typografická pisma latinková, which is an extensive compendium of knowledge about the script. The topic of typeface legibility is represented by the book by Bror Zachrisson Studia nad czytelnościa druku

25 Kuglin's typescript put in the book includes thanks submitted to Jan Dylik, Secretary General of the Łódź Scientific Society. 
(Studies in the legibility of printed text), popular in the 70ies, published in Warsaw in 1970. Kuglin's interests included also book illustration and its techniques. It is confirmed by the works on particular graphic techniques, among others the $18^{\text {th }}$ century edition of Die Kunst in Kupfer zu stechen published in Dresden in 1765, and Karl Golmert's Der lithographische Maschinendruck of 1921 (Leipzig), Lexikon der graphischen Technik published in Leipzig in 1967 and the others. Books on bookbinding can also be found in this collection, with particular attention put on Der Bucheinband. Ein Handbuch für Buchbinder und Büchersammler by Gustav Adolf Erich Bogeng, published in Halle in 1913 - the heavy volume concerning bookbinding: their history and development, types, the art of bookbinding, materials applied and different kinds of decoration. Kuglin owned also the Leipzing edition from 1925 of Der Bucheinband und die Pflege des Buches, the book by Douglas Cockerell, a student of Cobden-Sanderson.

Kuglin's collection reflects also the post-war stage of his interest in publishing scientific literature, in particular, typesetting of scientific editions. He gathered rich literature in Polish concerning either different typesetting techniques (manual or automatic typesetting and phototypesetting) or the art of typesetting editions of different character themselves. It includes for example instructions the published in Warsaw in 1953: Skład w językach obcych (Typesetting in foreign languages), Formowanie maszynowego sktadu tabel (Forming automatic typesetting of tables), Ręczny sktad formut matematycznych $i$ chemicznych (Manual typesetting of mathematical and chemical formulas) and the others. The collection reflects also Kuglin's engagement in activities for the development of Polish post-war printing sector. Literature concerning polygraphy stands out in terms of numbers. These are different handbooks concerning printing techniques: planographic printing, letterpress printing and intaglio (in particular offset, typography and rotogravure), application of adequate printing paints, types of paper and storage methods, material science in regard of polygraphy, etc. ${ }^{26}$ These texts are mostly in Polish, but also in Russian and Czech languages.

26 Among others: L. Kapłan, Praca metrampaża, Warszawa 1951; A. Pierow, Praca na maszynach dociskowych, Warszawa 1951; S. Ciupalski, Maszynoznawstwo poligraficzne. Part 1, Warszawa 1954; A. Jeger, Technologia druku wypuktego (typograficznego), Parts 1-3, Warszawa 1954; A. Rambousek, Sazba tabulek a vzorců na stroji monotype, Praha 1956; Dorociński Jan, Druk płaski. Parts 1-4, Warszawa 1954; Cz. Rudziński, Rotograwiura. Parts 1-2, Warszawa 1954; Cz. Gruszczyński, Farby graficzne. Technologia - stosowanie, Warszawa 1954; H. Piekarniak, Sterotypia, Warszawa 1954; R. Blāha, Fototypografie, Praga 1956; K. Pop, Organisace mezd v polygrafickém průmyslu, Praga 1958. 


\section{Special editions}

Among books concerning aesthetics of print, there are many positions distinctive in regard to edition accurateness. They are not only means of valuable content, but also a perfect example of the editing art. This concerns in particular German language publications. One cannot describe all of them here, however those the most interesting will be presented below.

Beautiful graphic design, fitting perfectly to presented content, is the feature of the two volume edition from 1910 concerning modern art of the book Die graphischen Künste der Gegenwart (Band 3). Das moderne Buch. It was developed by Ludwig Volkmann, the first President of the Deutschen Buchgewerbevereins, who in 1914 was also a chairman of the BUGRA exhibition of the artistic book in Leipzig. It was published in Stuttgart by Verlag von Felix Krais. This book is a model example of publication engaged in a fight for improving quality of publishing production, degraded by the technological development of the $19^{\text {th }}$ century, therefore it is worth to present fundamental remarks from the introduction. Volkmann underlined that huge economic development which took place in Germany in the second half of the $19^{\text {th }}$ century, admittedly resulted in great technological development, but to a detriment of book quality. Its mass production counted mostly, and another problem emerged. Particular professional groups which should cooperate for the book benefit (typesetters, illustrators, printers, bookbinders, booksellers, etc.) started to wander from each other, concentrating not on a book itself as a whole, but mostly on their profit. The book's aim is (among others) integration of dispersed professional community and recapturing the need for cooperation. It consists of texts written by different experts, concerning: application of adequate typefaces in typesetting, decorations and ornaments, typography, preparation and printing of illustration (lithography, chromolithography, screen printing, etc.), paper production, bookbinding, etc. More attention is put on preparation of special prints: maps, music notes, etc. Each article is completed with bibliography and rich illustration material, which is also a presentation of competencies of book professionals of that time, as well as a form of advertisement. Worth noting are illustrations with beautiful graphic, lettering, inserts from original and fine papers, as well as graphics presenting exemplary printing machines, etc. The edition was developed with the highest accuracy. The book is in a large format and attracts attention with elegant, classical typography, including noble proportions of columns and margins, subtle ornamentation, high quality of print and natural genre of paper. The whole makes a perfect source material to get knowledge not only about techniques of book production of that time, but also possibilities and binding trends in book decoration and illustrations. 
Original in form is the book by Karl Kasper Bunter Traum auf gewebtem Grund. Aus der wunderwelt des Stoffdrucks published in Berlin in 1938 by the Otto Elsner Verlagsgesellschaft. It is a story about (among others) history of dyeing and decorating materials with printing techniques from the ancient to modern times. Its characteristic element is extraordinarily rich illustration material, prepared with enormous precision and accuracy in mapping details. There are many colourful watercolours and drawings of Erwin Bindewald, presenting e.g. history of dyeing textiles, revealing technological arcana of production of coloured fabrics within centuries. Curiosities are presentations of different types of industrial machines. Besides watercolour illustrations, there are also pencil sketches in the book. One element is featured with colour on grey pictures - usually, it is the main character of a book or a textile band. The typography of the edition is extremely dynamic and includes any possible solutions characteristic for the books of that time, joining fluently text and image narration. It is completed with linen binding printed with colour patterns, which is a specific example of application of colour fabric.

A bit older is the edition of 1897 devoted to Jan Gutenberg Gutenberg. Sein Leben, sein Werk, sein Ruhm, published on the occasion of $500^{\text {th }}$ birthday anniversary of the famous printer. The book is written by Alfred Börckel, a librarian from the Municipal Library in Mainz. It was published by the Verlag von Emil Roth in Giessen, in the format $20 \times 28,5 \mathrm{~cm}$, and includes 34 black and white illustrations. It is the example of the noble art of typography. The column is built according to classic rules based on the golden division, surrounded by red, hair-thin lines going to bleed, reminding that proportions in the book are not accidental and dimensions of column and margins are important elements of the project. The book attracts attention to transparency and much light. The column is very legible and functional (verse width approx. 60 marks). Moreover, the reader's attention is attracted with delicate decorations: red initials and ornamental borders with floral motives, as well as ornamental leaves at pagination. A few illustrations are woodcut. Interesting in the title page in centred typesetting and Gutenberg's portrait at the blank page, separated from the title page with translucent tissue protecting graphic. The edition is completed with beautiful, ecru fabric binding with stamped decorations in brown and red colours. Central element of the cover is title, in upper position, where Gutenberg's name is typed with fraktur and distinguished with red colour. Under the name there is stamped medallion presenting the printer's portrait. The cover attracts attention with accumulation of decorative elements, typical of the $19^{\text {th }}$ century. The book has red spine and beautiful, patterned endpaper.

Among German language works concerning printing and history of the book, there is interesting, large yearbook published in 1925 by the Verlag der Gutenberggesellschaft in Mainz on the $25^{\text {th }}$ anniversary of the Gutenberg 
Museum in Mainz, Gutenberg. Festschrift zur Feier des 25 Jährigen Bestehens des Gutenbergmuseums in Mainz. It is the result of common effort of several dozens of people - outstanding scientists, book artists and printers, as it was presented in the introduction. The edition consists of texts in different languages (German dominates) concerning origins of print, printing in the years 1500-1900 and production of modern book. It attracts attention with accurate graphic design. It was published in quite a large format $22 \times 29 \mathrm{~cm}$. The column is surrounded by wide margins, expanding according to classical rules - from internal to lower margin $(3 ; 3 ; 3,5 ; 6 \mathrm{~cm})$. The column is dense, with 80 marks in a verse, typesetted with quite large point size 12/14. The element attracting particular attention is the noble typeface - Ehmcke Mediaeval - designed by Fritz Helmuth Ehmcke (1878-1965), a German designer, typographer and illustrator, professor of the Akademie der Bildenden Künste in Munich. Legible typeface is enriched with nautical digits and initials, e.g. beautiful Q letter with specifically elongated tail. Before the main text a whole page, coloured woodcut with Gutenberg's coat of arms is placed, made by Otto Hupp (1859-1949), a known German graphic designer and heraldic expert. The book is printed on ribbed paper and binded in canvas.

The beautifully edited book concerning calligraphy Meister der Schreibkunst aus drei Jahrhunderten of Peter Jessen, including 200 illustrated tables, was published in Stuttgart in 1923 by the Julius Hoffmann Verlag. It attracts attention with a large format $24,5 \times 33 \mathrm{~cm}$ and clearly designed, light, two columns surrounded by wide, classic margins. Copies were enumerated, what confirms its special character.

Presentation of all extraordinary positions here is impossible, however all the examples described above show that Kuglin's collection - slightly forgotten nowadays - is undoubtedly worth interest. It includes not only many valuable editions concerning aesthetic of print, but also many examples of masterful typography in beautiful, superb in form books, being therefore a perfect source for research on aesthetic of printing of the $20^{\text {th }}$ century. 
Photo 1-2. Jan Kuglin's exlibrises. Source: Library of the Institute of Information and Library Science, University of Wrocław. Photograper: W. Sierżęga.
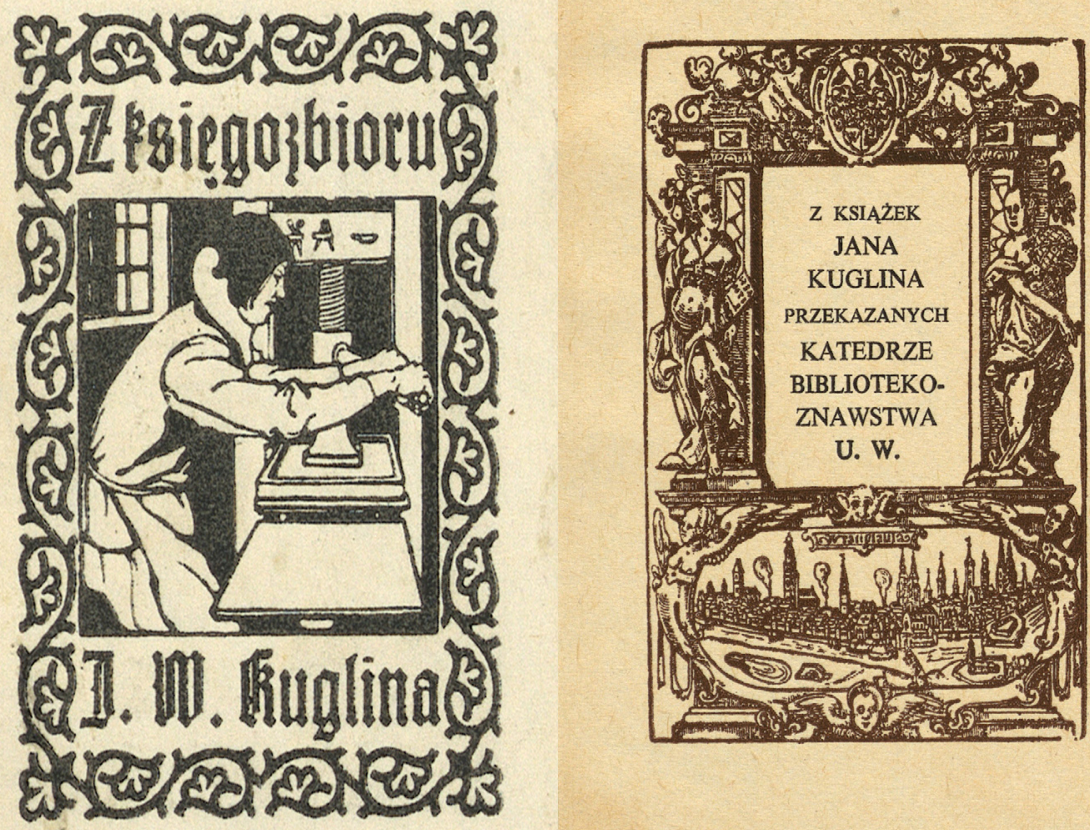

104 
Photo 3-4. Die graphischen Künste der Gegenwart. Das moderne Buch, ed. L. Volkmann, Stuttgart 1914. Source:Library of the Institute of Information and Library Science, University of Wrocław. Photograper: W. Sierżęga

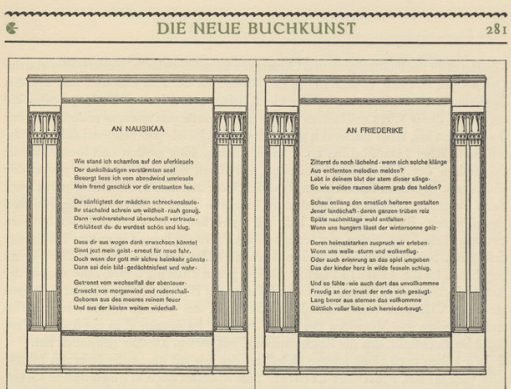

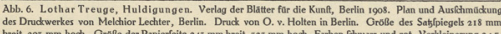

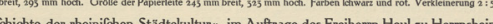
Cchichte der rheinilchen Städtekultur «, im Auftrage des Freiherrn Heyl zu Herrnsheim von Heinrich Boos verfalt und $1897-190$ r in 4 Bänden bei l. A. Stargardt in Berlin reichen lnitialen und Kopfleiften und Vignetten die alten Zeiten, die der $\mathrm{Gen}$ geilt-

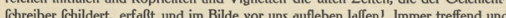
packend, bald mit tiefem realififichem Eroft, bald mit überlegenem Hum tren fol un in feinen derbkrätigen Linienzeichnungen nach der Art der alten deut for folgt er in leinen derbkrättigen Linienzeichnungen nach der Art der alten deutfchen Holz-
fchnittmeifter dem wechfelvollen Gange der Gelchichte der rheinichen Städte. Mit diefem Städtebuch haben wir ein illuftriertes deutches Gefchichtswerk bekommen, dem wir nur Kuglers Gefchichte Friedrichs des Großen mit den Holzchnitten Menzels an die Seite ftellen können. Aber Sattlers Bilder und Initialen unterbrechen nicht mehr den Text, fondern fie ordnen fich am Anfang und Ende der Kapitel dekorativ in das Buch ein. Die breite Schwabacher Type, in der Holten das Buch gedruckt hat, geht harmonich mit dem Bildichmuck zularmmen.

\& Eine noch umfangreichere Aufgabe wurde Sattler zuteil, als ihm die Reichsdruckere die künflterilche Ausgeltaltung ithrer Monumentalausgabe des Nibelungenliedes übertrug, die fie für die Parifer Weltausftellung von 1900 vorbereitete (Abb. 3-4). Die Nibelungen, das war wan wieder für den Küntler eine lockende Aufgabe zur Betätigun gerade feiner Kunft! Und es konnte ein Kunftwerk aus einem Guffe werden, weil der

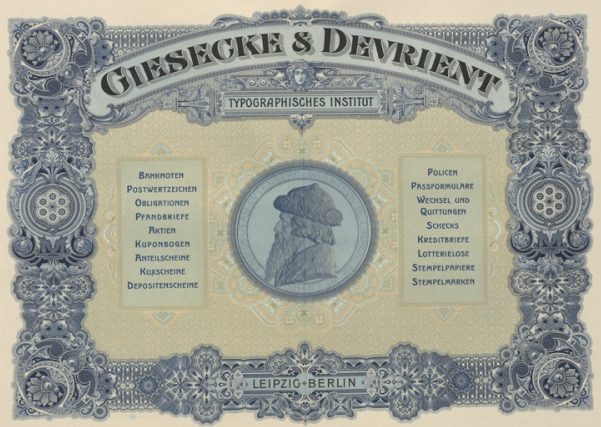


Photo 5-6. Karl Kasper, Bunter Traum auf gewebtem Grund. Aus der wunderwelt des Stoffdrucks, Berlin 1938. Source: Library of the Institute of Information and Library Science, University of Wrocław. Photograper: W. Sierżęga
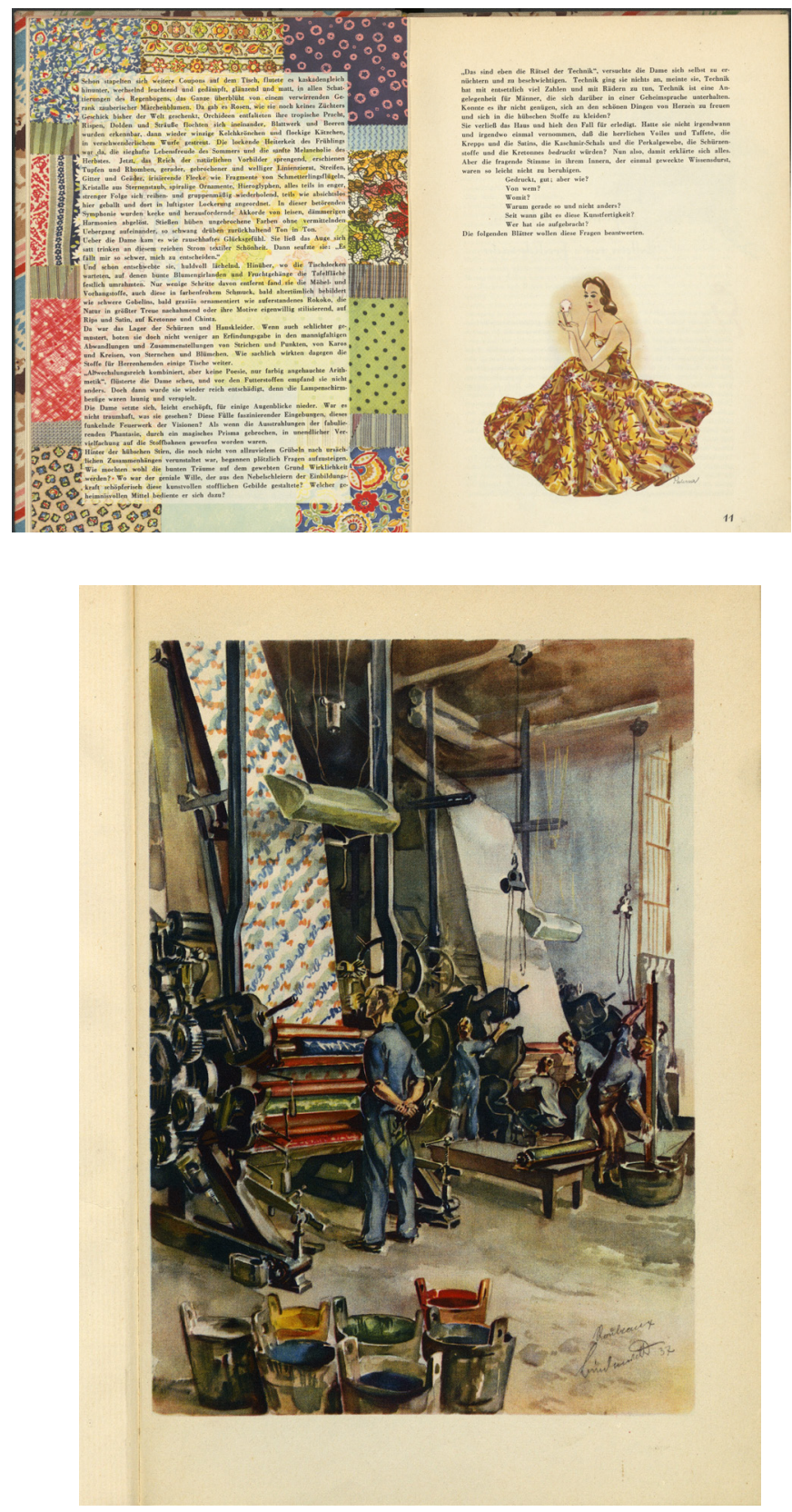
Photo 7. Alfred Börckel Gutenberg. Sein Leben, sein Werk, sein Ruhm, Moguncja 1897. Source: Library of the Institute of Information and Library Science, University of Wrocław. Photograper: W. Sierżęga

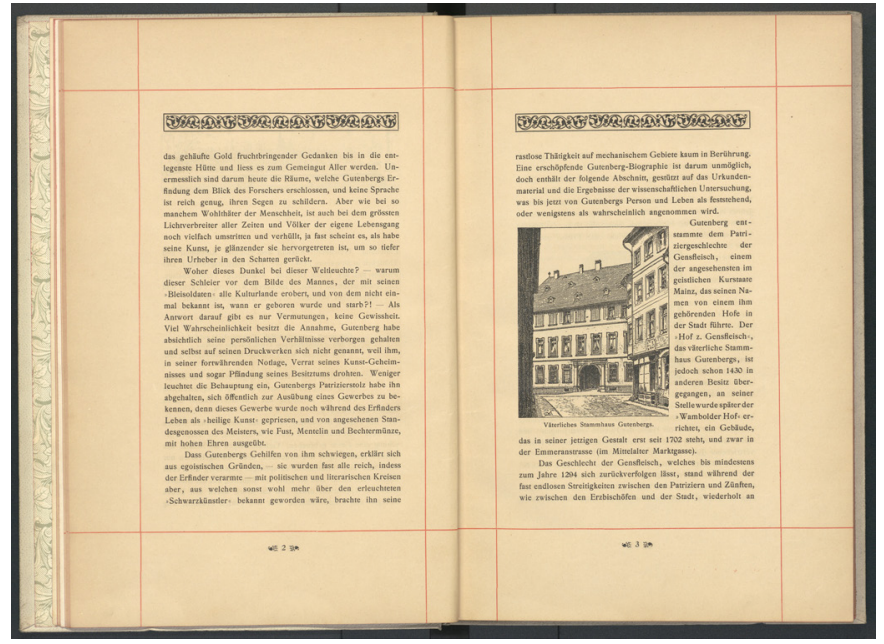

Photo 8. Gutenberg. Festschrift zur Feier des 25 Jährigen Bestehens des Gutenbergmuseums in Mainz, Moguncja 1925. Source: Library of the Institute of Information and Library Science, University of Wrocław. Photograper: W. Sierżęga
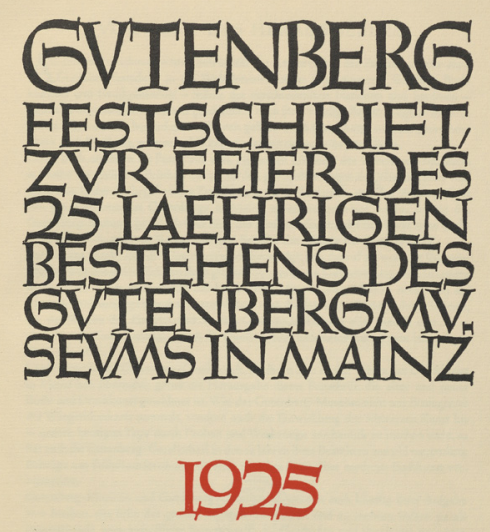

HERAVSGEGEBEN VON A.RVPPEL OVERLAG DER GVTENBER G' GESELLSCHAFT IN MAINZ 


\section{References}

Subject bibliography

Bednorz Z., Trud i dzieło pewnego «Ślężoka», “Odra” 1948, no. 48, pp. 3-4.

Franqueville d'Abancourt, H. de, Grafika książkowa Józefa Mehoffera na tle prądów współczesnych, Kraków 1929.

Gębczak M., Biblioteki Jana z Bogumina Kuglina, "Śląskie Miscellanea" 2004, t. 17, pp. 80-86 [online], http://www.sbc.org.pl/Content/88330/ii499767-0-17.pdf, [retrieved on 29.08.2018].

Gumuła U., Jan z Bogumina Kuglin - twórca pięknej książki, [in:] Książka polska na Ślasku w latach 1922-1945. Zarys problematyki, ed. by M. Pawłowiczowa, Katowice 1994, pp. 224-234.

Jesionowski A., Biblioteka Jana Kuglina, "Wici Wielkopolskie. Miesięcznik Poświęcony Sztuce i Kulturze” 1935, t. 5, no. 2 (41), p. 10.

Jesionowski A., Jan Kuglin - twórca pięknej książki, "Polska Zachodnia" 1934, no. 172, p. 3.

Kucharek J., Jan Kuglin - drukarz-bibliofil, MA thesis. Supervisor: S.J. Gruczyński, Wrocław 1976.

Kuglin J., Jak powstaje książka. Z cyklu «Przedmioty mówią», Series Biblioteka Szkoły Powszechnej, Lwów 1933, [online], http://dlibra.umcs.lublin.pl/dlibra/plain-conten$\mathrm{t}$ ? id=2660 [retrieved on 18.07.2018].

Kuglin J., Ze wspomnień typografa, Wrocław 1958.

Pokorzyńska E., Polska Gazeta Introligatorska. Dzieje czasopisma i analiza zawartości, [in:] Kazimierz Wielki University Repository, 2013, [online], http://repozytorium. ukw.edu.pl/handle/item/3842 [retrieved on 29.08.2018].

Radko J., Jan Kuglin, "Poglądy" 1971, no. 10 p. 4.

Rychlik T., Drukarz-artysta z Bogumina, "Zwrot” 1972, no. 11, pp. 25-26.

Skiba A., Doktor Jan z Bogumina Kuglin, "Wiadomości Graficzne” 1969, no. 3, p. 6.

Szulc-Golska B., Wielkopolskie biblioteki prywatne, Poznań 1929, [online], http://www. wbc.poznan.pl/dlibra/doccontent?id=17157 [retrieved on 7.07.2018].

Talar G., Jan z Bogumina Kuglin - drukarz i bibliofil (1892-1972), "Roczniki Biblioteczne" 1973, no. 1-2, pp. 417-436.

Talar G., Jan z Bogumina Kuglin, [in:] Stownik Pracowników Książki Polskiej. Suplement, Warszawa 1968, p. 113.

Objective bibliography

Blāha R., Fototypografie, Praga 1956.

Bogeng G.A.E., Der Bucheinband. Ein Handbuch für Buchbinder und Büchersammler, Halle 1913. 
Börckel A., Gutenberg. Sein Leben, sein Werk, sein Ruhm, Mainz 1897.

British Book Design, London 1957.

Ciupalski S., Maszynoznawstwo poligraficzne. Part 1, Warszawa 1954.

Cobden-Sanderson T.J., Das Idealbuch oder das schöne Buch. Eine Abhandlung über Kalligraphie, Druck und Illustration und über das schöne Buch als ein Ganzes, Berlin 1921.

Cockerell D., Der Bucheinband und die Pflege des Buches, Leipzig 1925.

Die graphischen Künste der Gegenwart (Band 3). Das moderne Buch, ed. by L. Volkmann, Stuttgart 1914.

Die Kunst in Kupfer zu stechen, Dresden 1765.

Dorociński J., Druk płaski. Cz. 1-4, Warszawa 1954.

Eckelmann H., Zur Entwicklung der Buchdruckschrift, Frankfurt 1950.

Formowanie maszynowego sktadu tabel, Warszawa 1953.

Franke C.A., Handbuch der Buchdruckerkunst, Weimar 1867.

Geschichte der Buchdruckerkunst, Leipzig 1940.

Golmert K., Der lithographische Maschinendruck, Leipzig 1921.

Gruszczyński Cz., Farby graficzne. Technologia - stosowanie, Warszawa 1954.

Gutenberg. Festschrift zur Feier des 25 Jährigen Bestehens des Gutenbergmuseums in Mainz, Mainz 1925.

Hlavsa O., Sedláček F., Typografická písma latinková, Prague 1957, 1960.

Jeger A., Technologia druku wypukłego. Cz. 1-3, Warszawa 1954.

Kapłan L., Praca metrampaża, Warszawa 1951.

Kasper K., Bunter Traum auf gewebtem Grund. Aus der wunderwelt des Stoffdrucksi, Berlin 1938.

Kautzscht R., Die Entstehung der Frakturschrift, Mainz 1922.

Klenkens Ch. H., Die Kunst der Letter, Leipzig 1940.

Lexikon der graphischen Technik, Leipzig 1967.

Meisner H., Luther J., Die Erfindung der Buchdruckerkunst, Leipzig 1900.

Meister der Schreibkunst aus drei Jahrhunderten, by P. Jessen, Stuttgart 1923.

Morison S., Grundregeln der typographie, Berlin 1955.

Morison S., Handbuch der Druckerkunst, Berlin 1925.

Müller A., Lehrbuch der Buchdruckerkunst, Leipzig 1913.

Piekarniak H., Sterotypia, Warszawa 1954.

Pierow A., Praca na maszynach dociskowych, Warszawa 1951.

Pop K., Organisace mezd v polygrafickém průmyslu, Prague 1958.

Rambousek A., Sazba tabulek a vzorcu na stroji monotype, Prague 1956.

Ręczny skład formut matematycznych i chemicznych, Warszawa 1953.

Renner P., Mechanisierte grafik. Schrift. Typo. Foto. Film. Farbe, Berlin 1930.

Rodenberg J., Die Druckkunst als Spiegel der Kultur in fünf Jahrhunderten, Berlin 1942.

Rudziński Cz., Rotograwiura. Cz. 1-2, Warszawa 1954.

Schottenloher K., Das alte Buch, Berlin 1919. 
Skład w językach obcych, Warszawa 1953.

Spiegel Deutscher Buchkunst, Leipzig 1956.

The Second International Exhibition of Book Design, London 1947.

Wetzig E., Ausgewählte Druckschriften, Leipzig 1925.

Williamson H., Methods of Book Design. The Practice of an Industrial Craft, London 1956.

Zachrisson B., Studia nad czytelnościa druku, Warszawa 1970. 